\title{
Penetrasi PV dan Ketidakseimbangan Beban Pada Feeder 1 Gardu Induk Wirobrajan
}

\author{
Desrita Pardi, S.T., M. Eng \\ Dinas Energi dan Sumber Daya Mineral Provinsi Sumatera Barat \\ Jalan Joni Anwar No. 85, Lapai Padang \\ Sumatera Barat, Indonesia \\ Email: desritapardi@mail.ugm.ac.id, desritapardi@gmail.com
}

\begin{abstract}
The generation of electricity using fossil fuels can increase global warming. To reduce the use of fossil fuels, it can be overcome by developing and utilizing Renewable Energy (EBT). The example of this EBT is Photovoltaic $(P V)$. The addition of $P V$ with varying penetration and placement has different effects on the power flow. On the other hand, the load umbalanced results in the appearance of a current in the neutral of the transformer. The current that flows in the neutral of this transformer causes losses, namely losses due to a neutral current in the transformer neutral conductor and losses due to a neutral current flowing to the ground. The aim of this research is to see the effect of PV entry into the system with different penetrations. PV addition at the near end of the load with penetration of $10 \%, 20 \%$ and $30 \%$ at $0.38 \mathrm{kV}$ caused losses to rise by $3.5 \mathrm{~kW}, 30.8 \mathrm{~kW}$ and $101.6 \mathrm{~kW}$, while PV additions in the middle of circuit with penetrations of $10 \%, 20 \%$ and $30 \%$ at $20 \mathrm{kV}$ helped reduce losses by $9.4 \mathrm{~kW}, 11.4 \mathrm{~kW}$ and $13 \mathrm{~kW}$. In addition, to see the system load flow when there is a load umbalanced on Wirobrajan substation feeder 1 which consists of 4 distribution areas, namely Ngestiharjo-pakuncen, Tegalrejo, Bumijo A and Bumijo B using ETAP (Electrical Transient Analyzer Program) 12.6.0.
\end{abstract}

Keywords : power flow, load umbalanced, losses, penetration, $P V$

\begin{abstract}
ABSTRAK
Pembangkitan listrik dengan menggunakan bahan bakar fosil dapat meningkatkan pemanasan global. Untuk mengurangi penggunaan bahan bakar fosil tersebut dapat diatasi dengan pengembangan dan pemanfaatan Energi Baru Terbarukan (EBT). Salah satu contoh dari EBT tersebut adalah Photovoltaic (PV). Penambahan PV dengan penetrasi dan penempatan yang bervariasi memiliki pengaruh yang berbeda-beda terhadap aliran daya. Disisi lain, ketidakseimbangan beban mengakibatkan munculnya arus di netral trafo. Arus yang mengalir di netral trafo ini menyebabkan terjadinya losses (rugi-rugi), yaitu losses akibat adanya arus netral pada penghantar netral trafo dan losses akibat arus netral yang mengalir ke tanah. Tujuan penelitian ini adalah untuk melihat pengaruh masuknya PV ke sistem dengan penetrasi yang berbeda-beda. Penambahan PV di ujung dekat beban dengan penetrasi $10 \%, 20 \%$ dan $30 \%$ pada tegangan $0,38 \mathrm{kV}$ menyebabkan losses naik sebesar 3,5 kW, 30,8 kW dan 101,6 kW, sedangkan Penambahan PV di tengah saluran dengan penetrasi $10 \%, 20 \%$ dan $30 \%$ pada tegangan $20 \mathrm{kV}$ membantu mengurangi losses sebesar $9,4 \mathrm{~kW}, 11,4 \mathrm{~kW}$ dan $13 \mathrm{~kW}$. Selain itu, untuk melihat load flow sistem saat terjadi ketidakseimbangan beban pada Wirobrajan substation feeder 1 yang terdiri dari 4 area penyaluran yaitu Ngestiharjo-pakuncen, Tegalrejo, Bumijo A dan Bumijo B dengan menggunakan ETAP (Electrical Transient Analyzer Program) 12.6.0.
\end{abstract}

Kata kunci-aliran daya, ketidakseimbangan beban, losses, penetrasi, PV. 


\section{Penetrasi PV dan Ketidakseimbangan Beban pada Feeder 1}

\section{PENDAHULUAN}

Saat ini Indonesia sedang melaksanakan pembangunan di segala bidang. Seiring dengan laju pertumbuhan pembangunan maka dituntut adanya sarana dan prasarana yang mendukungnya seperti ketersediaan tenaga listrik. Sehingga, tenaga listrik merupakan kebutuhan yang utama, baik untuk kehidupan sehari-hari maupun untuk kebutuhan industri. Penyediaan tenaga listrik yang stabil dan kontiniu merupakan syarat mutlak yang harus dipenuhi dalam memenuhi kebutuhan tenaga listrik [1]. Dari kapasitas listrik yang dibangkitkan saat ini, sebagian besar energi listrik dibangkitkan dari sumber energi konvensional seperti batu bara, minyak bumi dan gas alam. Akibatnya, dengan semakin meningkatnya kebutuhan energi listrik di Indonesia maka kebutuhan akan sumber energi fosil juga turut meningkat secara eksponensial. Padahal di sisi lain, sumber energi fosil jumlahnya terbatas dan semakin lama akan habis sehingga membahayakan ketersediaan energi di masa depan dan memperbesar risiko melemahnya ketahanan energi di Indonesia [2].

Penggunaan bahan bakar fosil juga meningkatkan emisi gas rumah kaca yang dapat menyebabkan pemanasan global. Untuk mengatasi masalah tersebut, diperlukan solusi jangka panjang yang berkelanjutan dan ramah lingkungan. Salah satunya adalah dengan pemanfaatan energi terbarukan. Pengembangan pemanfaatan energi terbarukan merupakan upaya yang harus didukung penuh oleh seluruh lapisan masyarakat. Ketergantungan akan energi fosil yang semakin menipis cadangannya akan membuat Indonesia mengalami krisis energi. Sejatinya, antisipasi terhadap krisis energi bisa diatasi yaitu dengan terus melakukan pemanfaatan terhadap EBT [3].

Tulisan ini membahas tentang penetrasi dan ketidakseimbangan beban di sistem tenaga listrik pada wilayah Yogyakarta yaitu wilayah kerja Wirobrajan substation feeder 1 yang terdiri dari 4 area penyaluran yaitu Ngestiharjo-pakuncen, Tegalrejo, Bumijo A dan Bumijo B dengan total daya input feeder untuk feeder sebesar 6,4 MW dan beban sebesar 6,8 MW. Untuk memenuhi kelebihan bebannya, Wirobrajan substation terinterkoneksi dengan GDN Substation sebagai penyumbang daya yang kurang.

Yogyakarta merupakan salah satu kota yang berada di Negara Indonesia, merupakan negara tropis dengan potensi energi surya yang sangat besar karena wilayahnya yang terbentang melintasi garis khatulistiwa, dengan besar radiasi penyinaran 4,80 $\mathrm{kWh} / \mathrm{m}^{2} /$ hari [4] dengan kuat penyinaran tersebut diharapkan Indonesia dapat memanfaatkan radiasi tersebut dan menambah kapasitas instalasi PV di seluruh dunia yang telah melampaui $300 \mathrm{GW}$ [5].

Pada tulisan ini pemasangan dan penambahan PV yang dilakukan sangat tergantung terhadap tingkat penetrasinya, lokasi instalasi PV, jenis, kapasitas dan topografi jaringan [6], [7]. Menghitung persenan penetrasi PV sangat diperlukan. Ini diharapkan dapat memenuhi kebutuhan beban dalam waktu dekat. PV dengan penetrasi yang tinggi, tidak boleh terjadi karena dapat membahayakan operasi yang stabil dari sistem daya.

Saat ini, integrasi sumber daya energi terbarukan dalam jaringan distribusi telah meningkat pesat. Instalasi Distributed Generation (DG) di jaringan distribusi memiliki banyak manfaat seperti mengurangi kemacetan jaringan, mengurangi kerugian dan meningkatkan efesiensi sistem. Namun, meningkatkan penetrasi DG khususnya PV atau photovoltaic dan sistem angin atau PLTBayu menyebabkan banyak masalah teknis dalam sistem distribusi yang mempengaruhi kualitas daya dan keandalan jaringan [8]. Penetrasi PV yang tinggi menyebabkan banyak masalah tegangan termasuk kenaikan tegangan karena aliran daya yang terbalik dan kondisi beban yang rendah, fluktuasi tegangan karena perubahan kondisi cuaca, dan ketidakseimbangan tegangan karena perbedaan konfigurasi PV [7]-[10].

Namun, dalam memenuhi kebutuhan tenaga listrik tersebut, terjadi pembagian beban-beban yang pada awalnya seimbang menjadi tidak seimbang karena ketidakserempakan waktu penyalaan beban-beban tersebut, maka menimbulkan hasil ketidakseimbangan beban yang berdampak pada penyediaan tenaga listrik.

Tujuan penelitian ini adalah untuk melihat pengaruh masuknya PV ke sistem dengan penetrasi yang berbeda-beda. Selain itu, untuk melihat load flow sistem saat terjadi ketidakseimbangan beban pada Wirobrajan substation feeder 1 yang terdiri dari 4 area penyaluran yaitu Ngestiharjo-pakuncen, Tegalrejo, Bumijo A dan Bumijo B dengan menggunakan ETAP (Electrical Transient Analyser Program) 12.6.0

\section{METODE PENELITIAN}

\subsection{Penetrasi PV}

Salah satu tantangan integrasi PV pada jaringan distribusi adalah kemampuan sistem dalam menyalurkan energi PV dengan tetap menjaga standar layanan dan operasi. Kapasitas maksimal PV yang diintegrasikan dinyatakan sebagai besar penetrasi, yaitu rasio kapasitas terpasang PV terhadap beban puncak sistem. Faktor pembatas utama penetrasi adalah 


\section{Penetrasi PV dan Ketidakseimbangan Beban pada Feeder 1}

pembebanan lebih pada saluran dan transformator serta kenaikan tegangan sistem.

Penempatan pada beberapa lokasi secara tersebar dapat meningkatkan batas penetrasi PV. Penetrasi PV dapat menurunkan rugi-rugi daya sistem, akan tetapi pada penetrasi yang tinggi rugi-rugi daya cenderung menjadi lebih besar.

Penelitian ini menggunakan beberapa metode, yaitu:

1. Penambahan pembangkitan intermitten (PLTS/PV) di ujung dekat beban dengan penetrasi $10 \%, 20 \%$ dan $30 \%$ pada tegangan $0,38 \mathrm{kV}$.

2. Penambahan pembangkitan intermitten (PLTS/PV) di tengah saluran dengan penetrasi $10 \%, 20 \%$ dan $30 \%$ pada tegangan $20 \mathrm{kV}$.

3. Penambahan pembangkitan intermitten (PLTS/PV) di pangkal saluran dengan penetrasi $10 \%, 20 \%$ dan $30 \%$ pada saluran $20 \mathrm{kV}$.

\subsection{Ketidakseimbangan Beban}

Ketidakseimbangan beban pada suatu sistem distribusi tenaga listrik selalu terjadi dan penyebab ketidakseimbangan tersebut adalah pada beban-beban satu fasa pada pelanggan jaringan tegangan rendah. Akibat ketidakseimbangan beban tersebut muncullah arus di netral trafo. Arus yang mengalir di netral trafo ini menyebabkan terjadinya losses (rugirugi), yaitu losses akibat adanya arus netral pada penghantar netral trafo dan losses akibat arus netral yang mengalir ke tanah.

Sebagai akibat dari ketidakseimbangan beban antara tiap-tiap fasa pada sisi sekunder trafo (fasa $\mathrm{R}$, fasa $\mathrm{S}$, fasa $\mathrm{T}$ ) mengalirlah arus di netral trafo. Arus yang mengalir pada penghantar netral trafo ini menyebabkan losses (rugi- rugi). Losses pada penghantar netral trafo ini dapat dirumuskan pada persamaan 1 .

dimana:

$$
P N=I N^{2} \times R N
$$

$\mathrm{PN}=$ losses pada penghantar netral trafo (watt)

IN = arus yang mengalir pada netral trafo (A)

$\mathrm{RN}=$ tahanan penghantar netral trafo $(\Omega)$

Sedangkan losses yang diakibatkan karena arus netral yang mengalir ke tanah (ground) dapat dihitung dengan perumusan persamaan 2 .

$$
P G=I G^{2} \times R G
$$

dimana:

$\mathrm{PG}=$ losses akibat arus netral yang mengalir ke tanah (watt)

IG = arus netral yang mengalir ke tanah (A)

$\mathrm{RG}=$ tahanan pembumian netral trafo $(\Omega)$
Yang dimaksud dengan keadaan seimbang adalah suatu keadaan di mana :

1. Ketiga vektor arus / tegangan sama besar.

2. Ketiga vektor saling membentuk sudut $120^{\circ}$ satu sama lain.

Kemungkinan keadaan tidak seimbang ada 3 yaitu:

1. Ketiga vektor sama besar tetapi tidak membentuk sudut $120^{\circ}$ satu sama lain.

2. Ketiga vektor tidak sama besar tetapi membentuk sudut $120^{\circ}$ satu sama lain.

3. Ketiga vektor tidak sama besar dan tidak membentuk sudut $120^{\circ}$ satu sama lain.
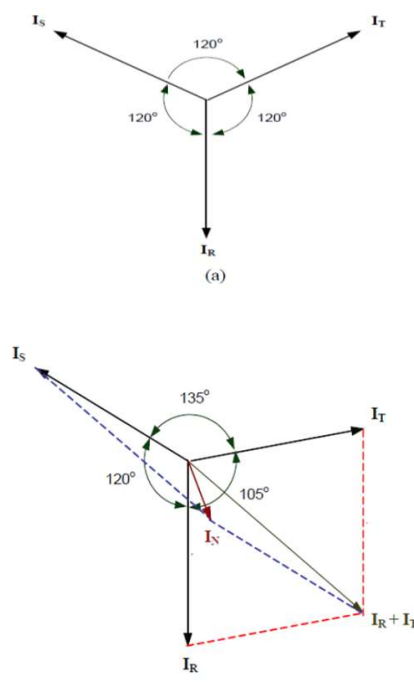

Gambar 1(a) dan 1 (b). Vektor Diagram Arus

Gambar 1(a), menunjukkan vektor diagram arus dalam keadaan seimbang, dimana terlihat bahwa penjumlahan ketiga vektor arusnya $\left(I_{R}, I_{S}\right.$, $\mathrm{I}_{\mathrm{T}}$ ) adalah sama dengan nol sehingga tidak muncul arus netral (IN). Sedangkan pada Gambar 1(b), menunjukkan vektor diagram arus yang tidak seimbang, dimana terlihat bahwa penjumlahan ketiga vektor arusnya $\left(\mathrm{I}_{\mathrm{R}}, \mathrm{I}_{\mathrm{S}}, \mathrm{I}_{\mathrm{T}}\right)$ tidak sama dengan nol sehingga muncul sebuah besaran yaitu arus netral (IN) yang besarnya bergantung dari seberapa besar faktor ketidakseimbangannya [1].

Untuk Penelitian ini digunakan beberapa metode, yaitu:

1. Ketidakseimbangan beban pada salah satu fasa tanpa PLTS/PV.

2. Ketidakseimbangan beban pada salah satu fasa dengan PLTS/PV. 


\section{HASIL DAN PEMBAHASAN}

3.1 Penetrasi PV

1 Penetrasi $10 \%$ di ujung beban dengan daya lebih kurang 640 watt dengan efisiensi 90\%. Sehingga didapatkan hasil sebesar $576 \mathrm{~W}$.

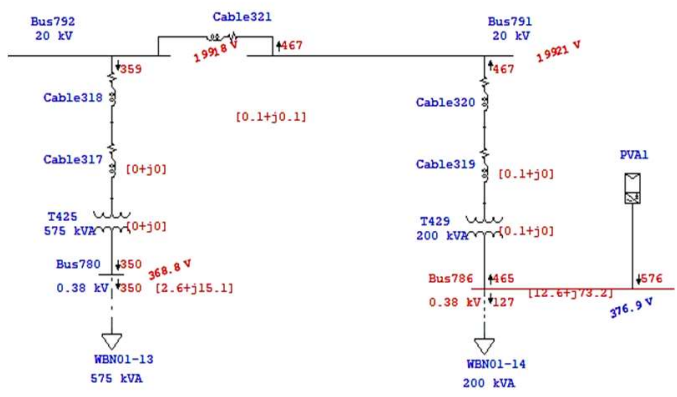

Gambar 2. Penetrasi 10\% di ujung beban

2 Penetrasi $10 \%$ di pangkal feeder dengan daya lebih kurang 640 watt dengan efisiensi 90\%. Sehingga didapatkan hasil sebesar 576 W.

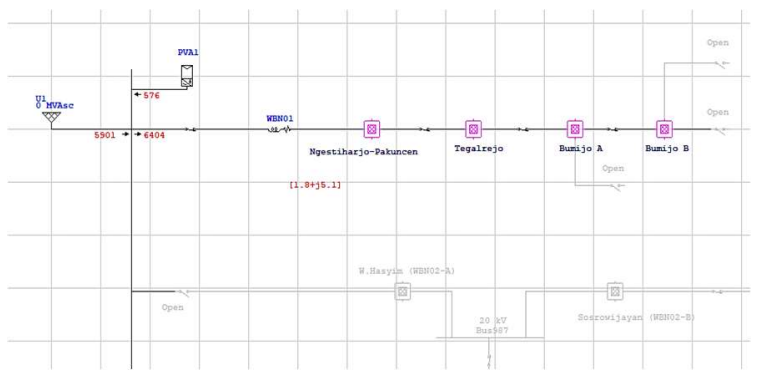

Gambar 3. Penetrasi 10\% di pangkal feeder

3 Penetrasi 10\% di tengah feeder dengan daya lebih kurang 640 watt dengan efisiensi $90 \%$. Sehingga didapatkan hasil sebesar $576 \mathrm{~W}$.

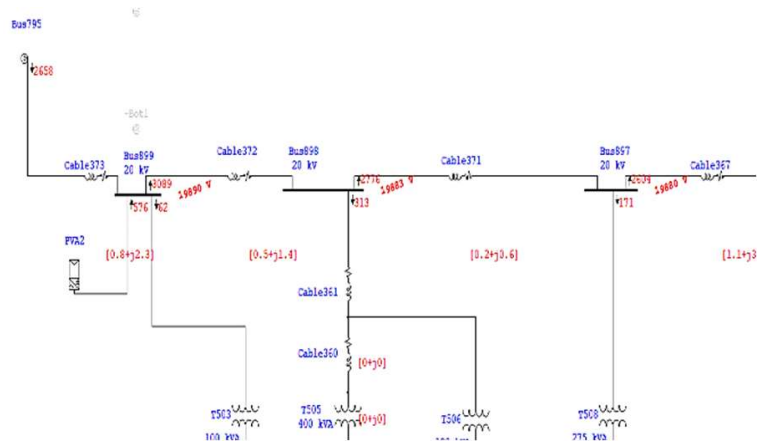

Gambar 4. Penetrasi 10\% di tengah feeder

4 Penetrasi $20 \%$ di ujung beban dengan daya lebih kurang 1280 watt dengan efisiensi 90\%. Sehingga didapatkan hasil sebesar $1153 \mathrm{~W}$.

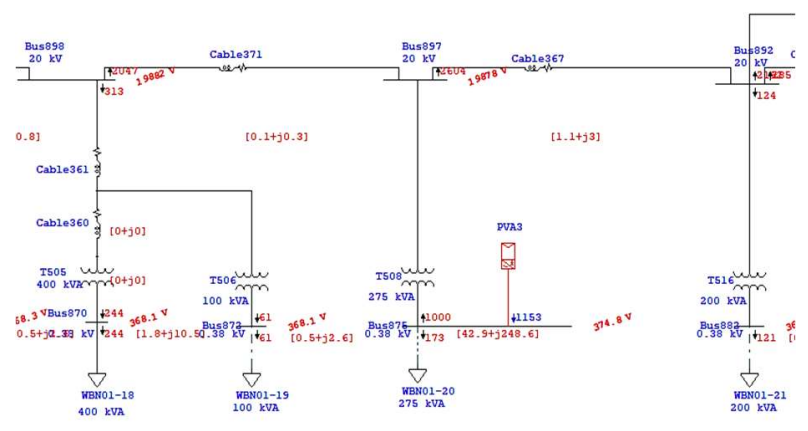

Gambar 5. Penetrasi 20\% di ujung beban

5 Penetrasi $20 \%$ di pangkal feeder dengan daya lebih kurang 1280 watt dengan efisiensi $90 \%$. Sehingga didapatkan hasil sebesar $1153 \mathrm{~W}$.

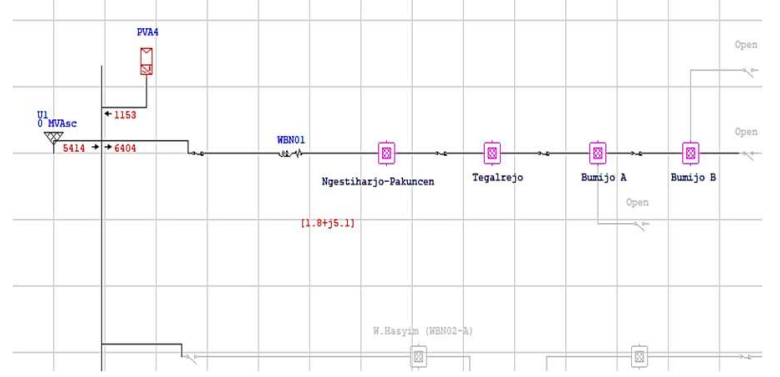

Gambar 6. Penetrasi 20\% di pangkal feeder

6 Penetrasi 20\% di tengah feeder dengan daya lebih kurang 1280 watt dengan efisiensi $90 \%$. Sehingga didapatkan hasil sebesar $1153 \mathrm{~W}$.

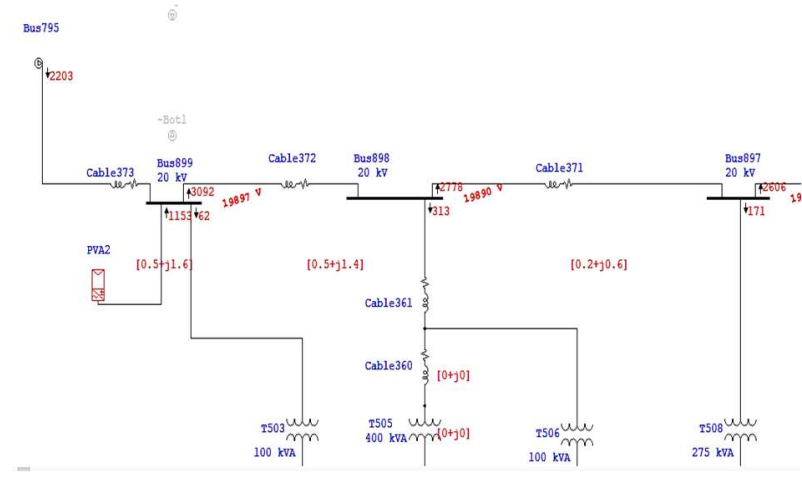

Gambar 7. Penetrasi 20\% di tengah feeder

7 Penetrasi $30 \%$ di ujung beban dengan daya lebih kurang 1920 watt dengan efisiensi 90\%. Sehingga didapatkan hasil sebesar $1728 \mathrm{~W}$. 


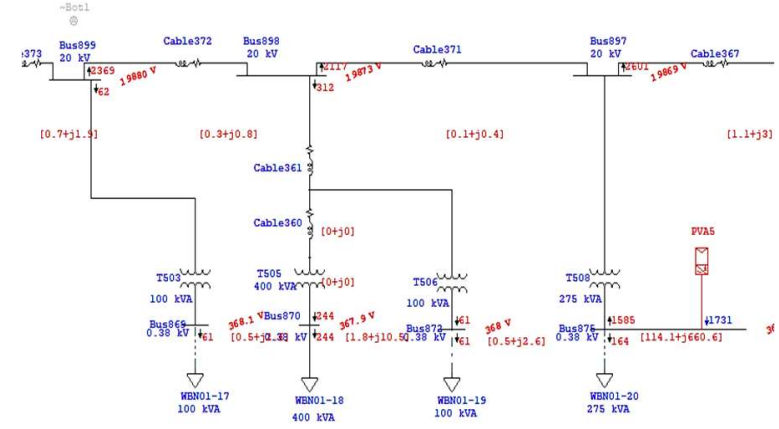

Gambar 8. Penetrasi 30\% di ujung beban

8 Penetrasi $30 \%$ di pangkal feeder dengan daya lebih kurang 1920 watt dengan efisiensi 90\%. Sehingga didapatkan hasil sebesar $1728 \mathrm{~W}$.

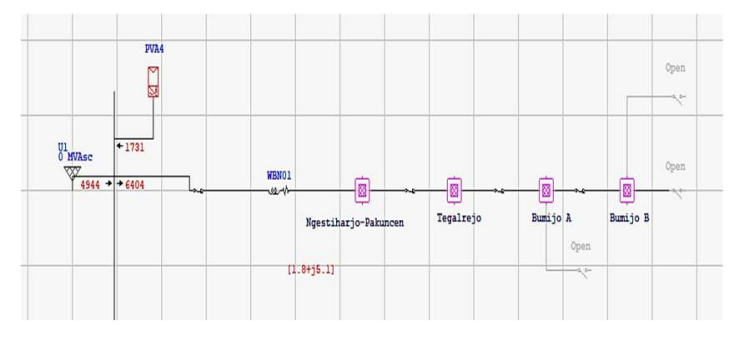

Gambar 9. Penetrasi 30\% di pangkal feeder

9 Penetrasi 30\% di tengah feeder dengan daya lebih kurang 1920 watt dengan efisiensi 90\%. Sehingga didapatkan hasil sebesar $1728 \mathrm{~W}$.

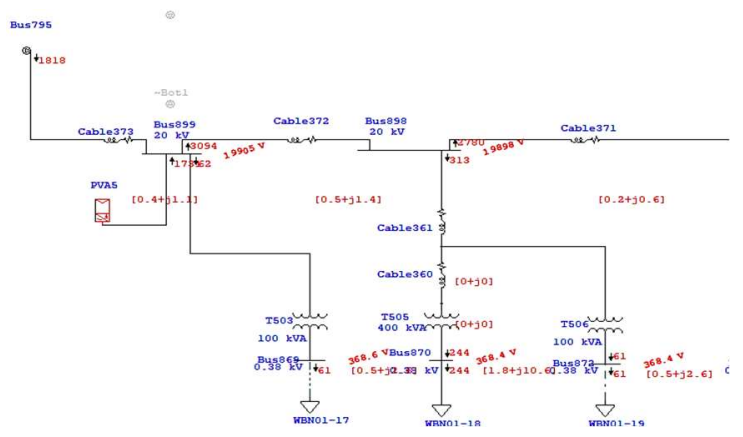

Gambar 10. Penetrasi 30\% di pangkal feeder

Total daya input feeder untuk feeder 1 Wirobrajan Substation sebesar 6,4 MW dengan beban sebesar 6,8 MW. Untuk memenuhi kebutuhan kelebihan beban tersebut, Wirobrajan substation di interkoneksi dengan GDN Substation sebagai penyumbang daya yang kurang, tetapi yang terjadi adalah underloaded (pembebanan yang kurang pada sistem) yang merupakan salah satu penyebab terjadi over voltage pada sistem.

Dari hasil penelitian diatas, dapat kita analisa bahwa :
1. Penambahan pembangkitan intermitten (PLTS/PV) di ujung dekat beban dengan penetrasi $10 \%, 20 \%$ dan $30 \%$ pada tegangan $0,38 \mathrm{kV}$ menyebabkan losses naik karena daya yang dimanfaatkan lebih kecil dari daya yang dihasilkan, akibatnya PLTS berfungsi sebagai pemberi daya reaktif, sehingga sisa daya dialirkan ke saluran $20 \mathrm{kV}$ dan menyebabkan losses.

Tabel 1. Kondisi sistem dengan PLTS di ujung dekat beban

\begin{tabular}{lcc}
\hline \multirow{2}{*}{$\begin{array}{c}\text { Kondisi } \\
\text { sistem }\end{array}$} & \multicolumn{2}{c}{ Losses } \\
\cline { 2 - 3 } & $\begin{array}{c}\mathbf{P} \\
(\mathbf{k W})\end{array}$ & $\begin{array}{c}\mathbf{Q} \\
(\mathbf{k V a r})\end{array}$ \\
\hline Normal & 67,4 & 340,1 \\
Penetrasi 10\% & 70,9 & 369,1 \\
Penetrasi 20 \% & 98,2 & 535,6 \\
Penetrasi 30 \% & 169 & 946,6 \\
\hline
\end{tabular}

2. Penambahan pembangkitan intermitten (PLTS/PV) di tengah saluran dengan penetrasi $10 \%, 20 \%$ dan $30 \%$ pada tegangan $20 \mathrm{kV}$ membantu mengurangi losses. Semakin tinggi persen penetrasi, semakin kecil losses.

Tabel 2. Kondisi sistem dengan PLTS di tengah saluran

\begin{tabular}{|c|c|c|}
\hline \multirow[b]{2}{*}{$\begin{array}{l}\text { Kondisi } \\
\text { sistem }\end{array}$} & \multicolumn{2}{|c|}{ Losses } \\
\hline & $\begin{array}{c}\mathbf{P} \\
(\mathbf{k W}) \\
\end{array}$ & $\begin{array}{c}\mathbf{Q} \\
\text { (kVar) } \\
\end{array}$ \\
\hline Normal & 67,4 & 340,1 \\
\hline Penetrasi $10 \%$ & 58 & 298,6 \\
\hline Penetrasi $20 \%$ & 56 & 292,9 \\
\hline Penetrasi $30 \%$ & 54,4 & 288,4 \\
\hline
\end{tabular}

3. Penambahan pembangkitan intermitten (PLTS/PV) di pangkal saluran dengan penetrasi $10 \%, 20 \%$ dan $30 \%$ pada saluran 20 $\mathrm{kV}$ membantu mengurangi losses. Kenaikan penetrasi tidak terlalu signifikan terhadap penurunan losses.

Tabel 3. Kondisi sistem dengan PLTS di pangkal saluran

\begin{tabular}{|c|c|c|}
\hline \multirow{2}{*}{$\begin{array}{l}\text { Kondisi } \\
\text { sistem }\end{array}$} & \multicolumn{2}{|c|}{ Losses } \\
\hline & $\begin{array}{c}\mathbf{P} \\
(\mathbf{k W})\end{array}$ & $\begin{array}{c}\mathbf{Q} \\
\text { (kVar) }\end{array}$ \\
\hline Normal & 67,4 & 340,1 \\
\hline Penetrasi $10 \%$ & 60,5 & 305,5 \\
\hline Penetrasi $20 \%$ & 60,5 & 305,5 \\
\hline Penetrasi $30 \%$ & 60,5 & 305,5 \\
\hline
\end{tabular}

\subsection{Ketidakseimbangan Beban}

Langkah awal untuk membuat keadaan tidak seimbang pada kasus Feeder 1 WBN 01 pada ETAP adalah dengan mengubah setting nilai MVAsc pada menu power grid editor dengan input nilai $\mathrm{kA}$ sebesar $16 \mathrm{kA}$ (standar nilai arus 


\section{Penetrasi PV dan Ketidakseimbangan Beban pada Feeder 1}

hubung singkat di sisi $20 \mathrm{kV}$ ) dan input nilai X/R dengan nilai 10 .

1. Terjadi ketidakseimbangan beban pada fasa $\mathrm{C}$ pada bus 795 (Tanpa PLTS)

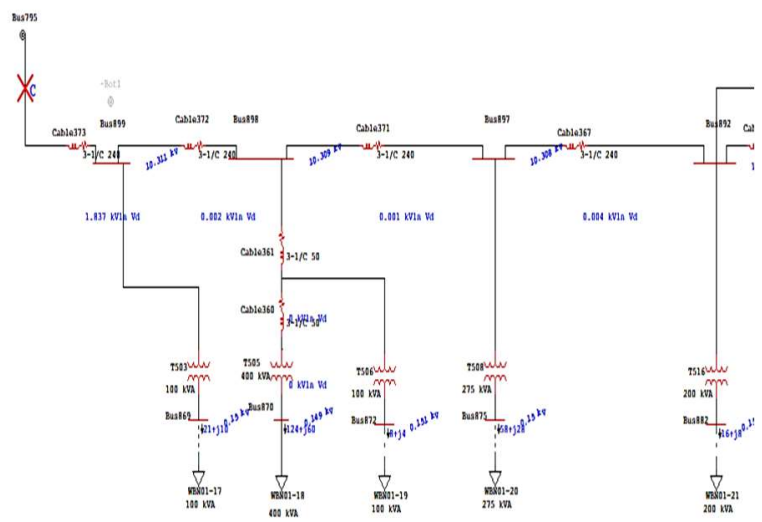

Gambar 11. ketidakseimbangan beban pada fasa C tanpa PLTS

2. Terjadi ketidakseimbangan beban pada fasa $\mathrm{C}$ pada bus 795 (Dengan PLTS)

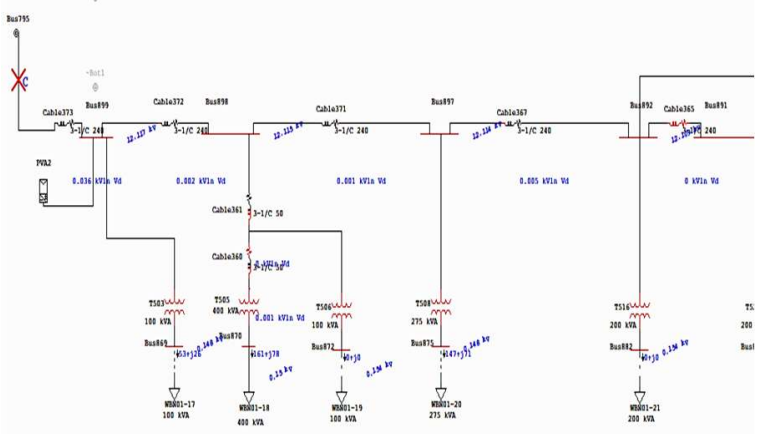

Gambar 12. ketidakseimbangan beban pada fasa C dengan PLTS

Dari hasil penelitian diatas, dapat kita analisa bahwa :

1. Terjadi ketidakseimbangan beban pada fasa $\mathrm{C}$ pada bus 795 (Tanpa PLTS). Losses Menjadi Sangat Besar, ini terjadi karena adanya ketidakseimbangan beban antara tiap-tiap fasa pada sisi sekunder trafo, sehingga arus muncul pada netral trafo. Dapat dilihat pada Gambar 13. Losses menjadi $118,9 \mathrm{~kW}$.

2. Terjadi ketidakseimbangan beban pada fasa $C$ pada bus 795 (Dengan PLTS). Losses Menjadi Sangat Besar jika dibandingkan dengan beban seimbang, tetapi jika dibandingkan dengan tanpa PLTS beban tidak seimbang lossesnya lebih kecil. Dapat dilihat pada Gambar 14. Losses menjadi 113,1 kW

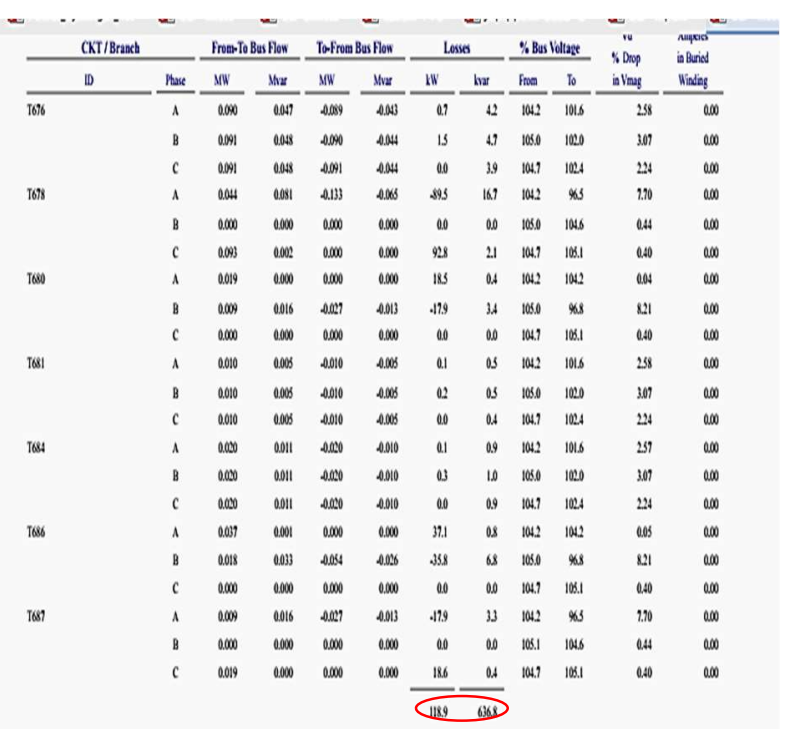

Gambar 13. Ketidakseimbangan beban tanpa PLTS

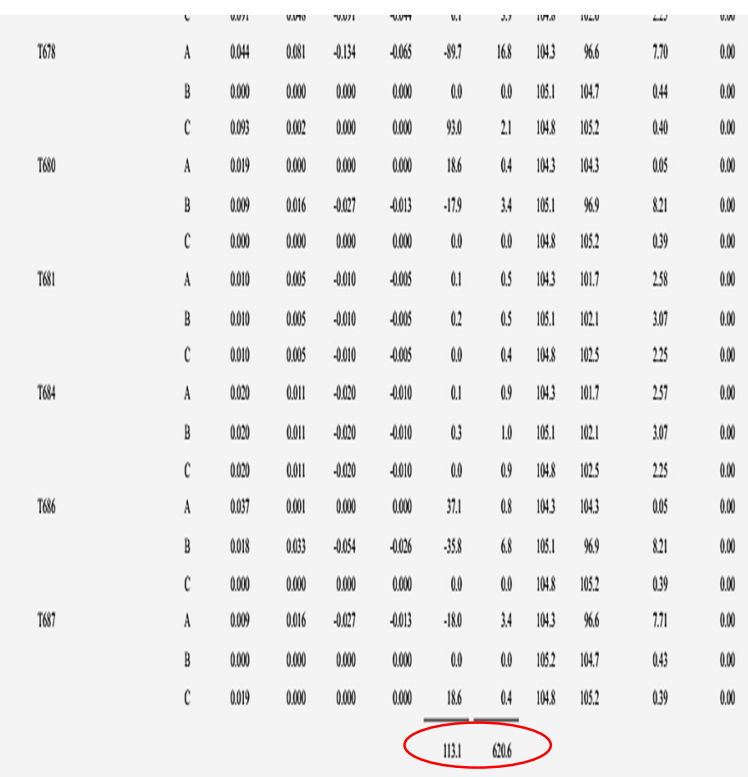

Gambar 14. Ketidakseimbangan beban dengan PLTS

Akibat ketidakseimbangan beban tersebut muncullah arus di netral trafo. Arus yang mengalir di netral trafo ini menyebabkan terjadinya losses (rugi-rugi), yaitu losses akibat adanya arus netral pada penghantar netral trafo dan losses akibat arus netral yang mengalir ke tanah.

\section{KESIMPULAN}

1. Over voltage pada sistem disebabkan oleh underloaded (pembebanan yang kurang pada sistem). Jika kondisi ini dibiarkan terus menerus dapat menyebabkan degradasi pada 
peralatan elektronik (berkurangnya masa penggunaan alat).

2. Penambahan pembangkitan intermitten (PLTS) di ujung dekat beban dengan penetrasi $10 \%, 20 \%$ dan $30 \%$ pada tegangan $0,38 \mathrm{kV}$ menyebabkan losses naik karena daya yang dimanfaatkan lebih kecil dari daya yang dihasilkan, akibatnya PLTS berfungsi sebagai pemberi daya reaktif.

3. Penambahan pembangkitan intermitten (PLTS) di tengah saluran dengan penetrasi 10 $\%$, 20\% dan $30 \%$ pada tegangan $20 \mathrm{kV}$ membantu mengurangi losses. Semakin tinggi persen penetrasi, semakin kecil losses.

4. Penambahan pembangkitan intermitten (PLTS) di pangkal saluran dengan penetrasi 10 $\%$, 20\% dan $30 \%$ pada saluran $20 \mathrm{kV}$ membantu mengurangi losses. Kenaikan penetrasi tidak terlalu signifikan terhadap penurunan losses.

5. Ketidakseimbangan beban mengakibatkan munculnya arus di netral trafo. Arus yang mengalir di netral trafo ini menyebabkan terjadinya losses (rugi-rugi), yaitu losses akibat adanya arus netral pada penghantar netral trafo dan losses akibat arus netral yang mengalir ke tanah.

\section{DAFTAR PUSTAKA}

[1] J. S. Setiadji, T. Machmudsyah, Y. Isnanto, and J. Siwalankerto, "Pengaruh Ketidakseimbangan Beban Terhadap Arus Netral dan Losses pada Trafo Distribusi," vol. 6, no. 1, pp. 68-73, 2006.

[2] F. Adzikri, D. Notosudjono, D. Suhendi, P. Studi, and T. Elektro, "STRATEGI PENGEMBANGAN ENERGI TERBARUKAN," pp. 1-13, 2014.

[3] "Program Strategis EBTKE dan Ketenagalistrikan," JURNAL ENERGI Media Komunikasi Kementerian Energi dan Sumber Daya Mineral, p. 100, 2016.

[4] P. H. Lumbangaol, "1 pendahuluan," no. 4, pp. 1-14, 2007.

[5] J. Yaghoobi, M. Islam, and N. Mithulananthan, "Analytical approach to assess the loadability of unbalanced distribution grid with rooftop PV units," Appl. Energy, vol. 211, no. December 2015, pp. 358-367, 2018.

[6] M. Ebad and W. M. Grady, "An approach for assessing high-penetration PV impact on distribution feeders," Electr. Power Syst. Res., vol. 133, pp. 347-354, 2016.

[7] F. Tursun, "Impacts of PV Installation on the Low Voltage Residental Distribution
Networks: A Case Study of Yildiz," no. May, pp. 13-17, 2013.

[8] A. Bedawy and K. Mahmoud, "Optimal Decentralized Voltage Control in Unbalanced Distribution Networks with High PV Penetration," no. December, pp. 19-21, 2017.

[9] Azzahra, S., Yogianto, A., \& Hajar, I. Studi Dampak Level Penetrasi Pembangkit Listrik Fotovoltaik pada Jaringan Distribusi. Energi \& Kelistrikan, 11(1), 1-8. 2019.

[10] Nurmela, Nurmela, and Nurul Hiron. " OPTIMASI KINERJA SISTEM PEMBANGKIT LISTRIK HYBRID." Journal of Energy and Electrical Engineering (JEEE) 1.12019. 